\title{
THE HETEROGENEOUS EFFECTS OF CSR DIMENSIONS ON FINANCIAL PERFORMANCE - A NEW APPROACH FOR CSR MEASUREMENT
}

\author{
Rongjia SUD1, Chunping LIU (D) ${ }^{*}$, Weili TENG (D)3 \\ ${ }^{1}$ College of International Studies, Sichuan University, No. 24 South Section 1, \\ Yihuan Road, 610065 Chengdu, China \\ 2, ${ }^{3}$ Nottingham Business School, Nottingham Trent University, Shakespeare Street, \\ Nottingham, NG1 4FQ, UK
}

Received 12 October 2019; accepted 27 March 2020

\begin{abstract}
This paper investigates the differential effects of corporate social responsibility (CSR) dimensions on corporate financial performance (CFP) across sectors in China. This research uses a unique data set provided by China Stock Market and Accounting Research (CSMAR), showing expenditure on CSR programs from 568 Chinese publicly traded firm-year observations from 2008 to 2017. Compared to previous studies using scores produced by extra-financial rating agencies, this research quantifies CSR efforts by corporate expenditure on CSR practices, which offers quantitative and precise information in explaining the CSR-CFP link. The results show that the dimension of the environment has negative effects on financial performance in capital-intensive manufacturing industries. The impact of HR expenditure on CFP is negative in the tertiary sector and resourceintensive manufacturing industries. However, CSR investments in the community are positively related to financial performance in resource-intensive industries and other secondary sector (mining, construction, and utilities). Firms, in general, could gain benefits when spending more on business and financial stakeholders.
\end{abstract}

Keywords: corporate social responsibility, corporate financial performance, stakeholder theory, extra-financial rating agencies, human resources, community, environment, business and financial stakeholders.

JEL Classification: M14, M21, M41.

\section{Introduction}

The issue whether corporate social responsibility (CSR) contributes to corporate financial performance (CFP) has great implications on CSR decision makings in a firm (Kao et al., 2018). Hence, a great number of studies have been conducted to examine whether the market rewards firms undertaking CSR activities (Albuquerque et al., 2019; Bhattacharya et al., 2020;

*Corresponding author. E-mail: chunping.liu@ntu.ac.uk 
Cheung et al., 2012). Empirical research in this area mainly investigated developed countries (the United States and European countries) and usually revealed the positive link between CSR efforts and financial performance (Kao et al., 2018). However, differences in the corporate environment and national environment make the concept of CSR highly contextual (Fukukawa \& Moon, 2004; Maignan \& Ralston, 2002). In emerging markets, such as China, CSR has attracted increasing interest from academics and the business community (Li \& Zhang, 2010; Reimsbach et al., 2018). Firms in emerging economies and developed markets vary in organisational behaviours (Fan et al., 2011). Therefore, mechanically applying CSR findings drawn from developed economies to emerging markets may not have a good fit. As the world largest emerging economy, China offers a different social and economic context to explore the relationship between "doing good" and "doing well". Given the diversity in markets and institutional circumstances in China (Wang \& Qian, 2011), this study can identify potential factors that may affect the CSR-CFP link. This study can provide guidance to Chinese firms in the CSR campaign. Findings can also be relevant for firms in other emerging economies.

This study has three goals. Firstly, this research examines specific CSR activities of publicly listed firms in China from 2008 to 2017 and then group them into four dimensions to quantify the levels of the CSR involvement. Secondly, this study explores the link between different CSR dimensions and CFP to see whether "doing-good" will result in "doing-well" in the Chinese market. Characterising CSR efforts by corporate expenditure on CSR-related management practices enables us to evaluate CSR efforts more precisely. Thirdly, the study assesses the heterogeneous effects of different CSR dimensions on CFP across industries. In addition to constructing an overall model with industry as the control variable to capture industry effects, this study also investigates the CSR-CFP link in various industries, including manufacturing industries (resource-intensive, capital-intensive and labour-intensive industries), other secondary sector (mining, construction, utilities) and tertiary sector.

This research contributes to the literature in the following ways. First, the research uses a unique data set provided by China Stock Market and Accounting Research (CSMAR) CSR report details, showing expenditure on CSR programs by Chinese publicly listed firms from 2008-2017. CSR efforts are quantified by spending on CSR related management practices. Previous research relies on ratings or scores produced by extra-financial rating agencies, such as Vigeo in Europe or Kinder, Lydenburg, Domini (KLD) in the United States to measure CSR (Crifo et al., 2016). However, the evaluation on CSR was rated by Vigeo or KLD, not by the firms themselves (Cavaco \& Crifo, 2014), which has been deemed not transparent (Chatterji et al., 2009). Instead, this paper quantifies CSR efforts by corporate expenditure on CSR practices, which offers quantitative and precise information in explaining the CSR-CFP link.

Second, this paper explores whether the effect of CSR on firm performance is heterogeneous across industries. The majority of previous research have controlled for industrial drivers of financial performance without considering industry influences on the CSR-CFP link (Hoepner \& Yu, 2010). Although many studies targeted at certain industries, such as construction industry (Jiang \& Wong, 2016), tourism-related industries (Inoue \& Lee, 2011), hospitality industries (Rhou, \& Singal, 2020), manufacturing industry (Torugsa et al., 2012), as well as restaurant industry (Rhou et al., 2016), this study presents an overall picture on various industry types, including manufacturing industries, other secondary sector and ter- 
tiary sector. More importantly, this research investigates the industrial heterogeneity in the relationship between each CSR dimension and financial performance. This finding helps companies in different sectors carry out more targeted and effective CSR initiatives.

The remainder of the paper is structured as follows. Section "Theoretical Background" reviews theoretical framework and discuss insights from the literature on CSR dimensions and CFP. Section "Methodology and Data" explains the data and research method. Section "Empirical analysis" presents the findings on the effect of each CSR dimension on financial performance across industries, key findings are also discussed in this part. Section "Conclusions" provide summary of findings, practical implications, limitations, as well as offer possible avenues for future research.

\section{Theoretical background}

\subsection{Corporate social responsibility}

Corporate social responsibility can be defined as the voluntary commitment made by a firm to surpass the conventional explicit and implicit obligations society expects (Falck \& Heblich, 2007). CSR consists of considerations given to customers, suppliers, employees, stockholders, environment, and community (Contini et al., 2020; Flammer et al., 2019; Girerd-Potin et al., 2014). To operationalize CSR, previous studies point out that CSR comprises several dimensions, and each dimension is composed by a group of voluntary activities (Clarkson, 1995; Godfrey \& Hatch, 2007; Waddock \& Graves, 1997). The most frequently used one is Carroll's division of corporate social responsibility into economic, legal, ethical and philanthropic responsibilities (Carroll, 1991). However, ethical and philanthropic dimensions are hard to be operationalized in empirical research due to ambiguous boundary (Clarkson, 1995; Schwartz \& Carroll, 2003).

Avetisyan and Ferrary (2013) propose a new perspective, conceptualising CSR as an emerging area consisting of CSR rating agencies and stakeholders. A stakeholder refers to any person or group who can influence or be influenced by the attainment of corporate goals (Freeman, 1984). Primary stakeholders include creditors, shareholders, employees, suppliers, customers, public interest groups, and the natural environment (Clarkson, 1995; Freeman, 1984). There are different rights and interests among stakeholders (Clarkson, 1995). The main goal of a company is to acquire the capability to balance the competing demands of different stakeholders (Roberts, 1992). Hence, targeted measures and programs are required to meet the different expectations of stakeholders to accomplish excellent financial performance (Peloza \& Papania, 2008). Voluntary activities targeted at different stakeholders should manifest distinct CSR dimensions (Clarkson, 1995; Peloza \& Papania, 2008).

\subsection{Extra-financial rating agencies and their dimensions}

Extant studies measure CSR using dimensions provided by extra-financial rating agencies, such as Vigeo in Europe or the KLD in the United States (Crifo et al., 2016). Extra-financial rating agencies provide investors with more comprehensive CSR information by a number of sub-ratings (Girerd-Potin et al., 2014). While community, corporate governance, human 
resources, environment, and human rights are five CSR dimensions both Vigeo and the KLD rating value, KLD pays special attention to diversity (Vigeo considers this in human rights) and product (Vigeo cares about business behaviour) (Girerd-Potin et al., 2014). Building on the stakeholder framework proposed by Clarkson (1995), five CSR dimensions in Vigeo or KLD data reflecting primary stakeholder issues have been widely used: environment, corporate governance, business behaviours towards customers and suppliers, community involvement, as well as human resources (Forget, 2012).

However, researchers hold divergent views on whether a number of categories should constitute one dimension or each category represents one dimension (Inoue \& Lee, 2011; Johnson \& Greening, 1999; Kacperczyk, 2009). Corresponding to main stakeholders identified by Clarkson (1995), Girerd-Potin et al. (2014) consider business stakeholder as a proxy for employees, customers and suppliers, and use financial stakeholders to represent stockholders and creditors. Although included by Girerd-Potin et al. (2014) in business stakeholders, employee issue shows corporate attention in human resources. Given the role it plays on business operation and financial performance, this paper regards it as another primary stakeholder issue and use human resources as a single CSR dimension. Since supplier and creditor items are not specified for all firms in this dataset, this study combines issues concerning customers, suppliers, stockholders and creditors into one dimension called business and financial stakeholders to include more companies in the sample. Based on prior research (Cavaco \& Crifo, 2014; Forget, 2012; Girerd-Potin et al., 2014; Inoue \& Lee, 2011), this paper proposes that CSR can be composed of four dimensions: (1) human resources (proxy for employees, denoted as HR), (2) community, (3) environment (4) business and financial stakeholders (proxy for customers, suppliers, stockholders, and creditors, denoted as BFS).

\subsection{Multidimensionality of corporate financial performance}

Different types of measures were used in examining corporate financial performance (Alshehhi et al., 2018). To capture short-term profitability and assess future profitability, extant studies often employ two kinds of indicators to represent CFP, accounting- and market-based measures (Inoue \& Lee, 2011; Luo \& Bhattacharya, 2006; McGuire et al., 1988).

Accounting-based performance measures, such as net profit margin (NPM) and return on assets (ROA) are backwards-looking indicators and reflect the historical financial performance (Cavaco \& Crifo, 2014). NPM is the net income divided by sales revenue (Sroufe \& Gopalakrishna-Remani, 2018). It shows the firm's capability to generate net profit from its sales. NPM has been commonly used in the literature studying the association between social and financial performance (Hermawan \& Mulyawan, 2014; Kamatra \& Kartikaningdyah, 2015; Sroufe \& Gopalakrishna-Remani, 2018). Another proxy of profitability is ROA, which is the net income divided by the average total assets (Reimsbach et al., 2018; Wang et al., 2008; Xu \& Zeng, 2016). It measures management efficiency in using assets to earn income and thus represents the firm's profitability (Forget, 2012).

Additionally, market-based measures, such as Tobin's Q, can serve as a substitute for accounting-based measures (Lee \& Jang, 2007). Tobin's Q reveals the assessment investors make on the corporate capability to create future earnings (Cavaco \& Crifo, 2014; Luo \& 
Bhattacharya, 2006; McGuire et al., 1988). The forward-looking measure can thus be adopted to identify the estimated future influence of CSR on financial performance (Cavaco \& Crifo, 2014; Hillman \& Keim, 2001). In this study, this paper uses three indicators to reflect different perspectives on financial performance, including accounting indicators, such as NPM and ROA, and a market-based measure, Tobin's Q.

\subsection{Effects of CSR dimensions on financial performance}

The study conducted by Daszynska-Zygadlo, Slonski, and Zawadzki (2016) proves the contingency of CSR performance across sectors. They use Thomson Reuters ASSET4 database to examine the impact of 3 CSR dimensions (environment, social and corporate governance) on financial performance in 10 Global Industry Classification System (GICS) sectors. This sample data cover 2428 companies from all over the world in the period of 2009-2012. They find the consumer staples sector is only sensitive to governance and environmental efforts; only environment initiatives are significant for healthcare and energy sector; and social dimension can positively affect financial performance in financials and utilities.

The CSR's impact on financial performance may also be contingent upon which CSR dimension is considered (Crifo et al., 2016). Some studies on the relationship between CSR dimensions and financial performance suggest mixed results, showing a positive, negative or neutral association between market value and each CSR dimension (Girerd-Potin et al., 2014). As for environment, the study conducted by Galema, Plantinga, and Scholtens (2008) find environment has positive impacts on market value. However, several studies reveal that the link between environment and firm performance is negative or insignificant (Barla, 2007; Filbeck \& Gorman, 2004). Similar results are also found for employee and community dimensions. Human resource management seems to influence firm performance positively (Huselid, 1995) or exert a negative effect (Gimenez et al., 2012). Brammer, Brooks, and Pavelin (2006) point out that involvement in the local community is negatively associated with firm performance, while Kacperczyk (2009) identifies the positive effect of community on market-based performance. Furthermore, Galema et al. (2008) find the effect of community is insignificant.

There are also mixed results about business and financial stakeholders. The study done by Wen and Fang (2008) shows that financial stakeholders do not affect financial performance significantly. Forget (2012) reveals good business behaviour with customers and suppliers is linked with better financial performance. On the other hand, Reitzig and Wagner (2010) conclude that improving relations with suppliers can affect firm performance negatively because it gives rise to non-learning opportunity costs.

Based on the prior research, it can be seen that CSR is a multi-dimensional construct whose dimensions have variant impacts on firm performance (Crifo et al., 2016; Forget, 2012). Several factors may account for the differences. Firstly, different measurements are used for financial performance (Alshehhi et al., 2018). Some research focuses on investigating accounting-based indicators, such as ROA, NPM, ROE or ROI; while others look into market-based indicators, such as Tobin's Q or market-to-book ratio. Secondly, different dimensions are employed to represent the CSR construct. Studies examining European firms 
mainly rely on Vigeo dimensions (Girerd-Potin et al., 2014), while research concerning US firms use KLD dimensions (Reimsbach et al., 2018; Turban \& Greening, 1997; Waddock \& Graves, 1997). Furthermore, findings vary with the country, industry, or company they investigate (Alshehhi et al., 2018). Although there appear mixed results, a positive influence of CSR on financial performance dominates the literature (Alshehhi et al., 2018). Thus, this research proposes the following hypotheses:

Hypothesis 1 (H1): CSR practices in human resources positively affect corporate financial performance

Hypothesis 2 (H2): CSR practices in community positively affect corporate financial performance

Hypothesis 3 (H3): CSR practices in environment positively affect corporate financial performance

Hypothesis 4 (H4): CSR practices in business and financial stakeholders positively affect corporate financial performance

Therefore, this paper aims to individually investigate the impacts of the four CSR dimensions on a firm's short-term and long-term profitability across industries (see Figure 1).

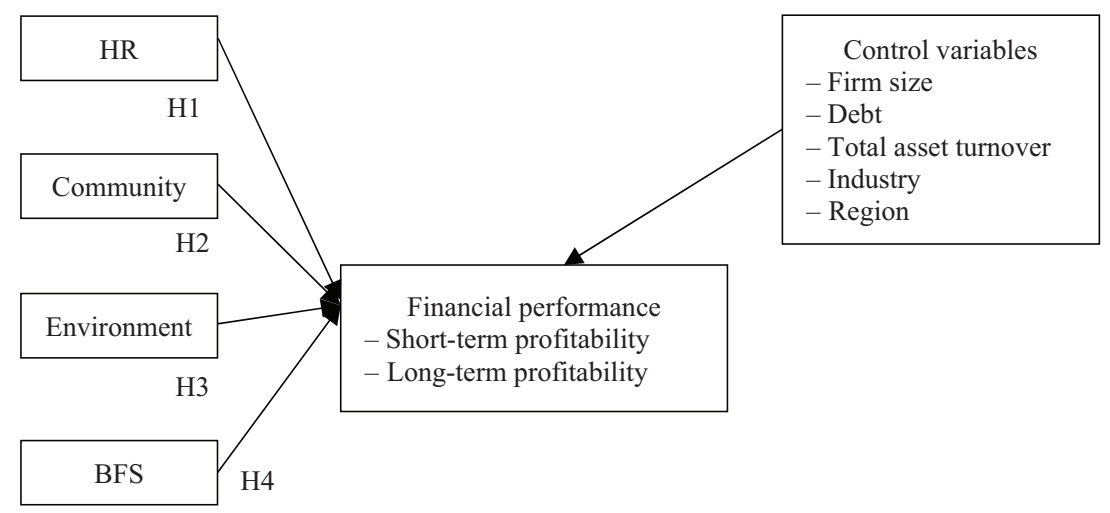

Figure 1. Theoretical model

\section{Methodology and data}

\subsection{Data selection}

This paper uses annual data from publicly listed firms of the Shanghai and Shenzhen stock exchanges in China. This sample covers a 10-year period from 2008 to 2017. CFP indicators and CSR report were taken from the China Stock Market and Accounting Research (CSMAR) database. This database established by Shenzhen GTA Education Technology (2000) is the main source for financial and non-financial information of public-listed firms in China.

The CSR report derived from CSMAR database lists 26527 CSR activity items which have been grouped into nine categories: corporate governance, employee relations, safety conditions, environment and sustainable development, public relations and philanthropy, the protection of stockholders' rights, the protection of creditors' rights, customer issues, 
and supplier issues. These activities are measured in both financial and non-financial ways. Non-financial CSR activities take different forms and vary across companies, certain CSR programs conducted by one firm are not seen in others, which are not comparable and hard to compute. To compare CSR engagement with a unified standard, this paper only chooses financial contributions, which are CSR activities listing annual corporate expenditure. Compared to previous studies using scores produced by extra-financial rating agencies (Crifo et al., 2016), this study quantifies CSR efforts by corporate expenditure on CSR practices, which offers quantitative and precise information in explaining the CSR-CFP link. After the selection, corporate governance which lists no financial investments was excluded, 8 categories were left. This paper then merged CSR data with CFP indicators and removed missing observations, the unbalanced panel dataset comprises 568 firm-year observations.

\subsection{Measurements of variables}

\subsubsection{CSR dimensions}

Based on the stakeholder framework proposed by Clarkson (1995), along with CSR dimensions provided by KLD and Vigeo, this study further groups 8 CSR categories in this dataset into four broad dimensions representing primary stakeholder issue to reflect CSR efforts. Employee relations and safety conditions can be represented by the dimension human resources; public relations and philanthropy reflect the dimension community; environment and sustainable development concerns the dimension environment. This paper combines the protection of stockholders' rights, the protection of creditors' rights, customer issues, and supplier issues into one dimension called the business and financial stakeholders based on an earlier study conducted by Girerd-Potin et al. (2014). They consider business stakeholder as a proxy for employees, customers and suppliers, and use financial stakeholders to represent stockholders and creditors. This study puts business stakeholders and financial stakeholders together under one dimension to include more companies and have more data, because supplier and creditor items are not specified for all firms. Unlike Girerd-Potin et al. (2014), this study singles employee out as a CSR dimension (human resources) due to the importance it has on business operation and financial performance. The further integration of dimensions is motivated by the fact that not each company invest in all 8 types of CSR activities, and there are missing data over all 8 CSR categories. This is similar to the concern mentioned by Cavaco and Crifo (2014). Therefore, this paper proposes that CSR can be composed of four dimensions: (1) human resources (proxy for employees), (2) community, (3) environment, (4) business and financial stakeholders (proxy for customers, suppliers, stockholders, and creditors), which are among the most commonly measured dimensions of corporate social responsibility (Cavaco \& Crifo, 2014; Forget, 2012; Girerd-Potin et al., 2014; Inoue \& Lee, 2011).

The CSR report from CSMAR lists the expenditure on each CSR activity independently. Since several activities can jointly represent one CSR dimension, this paper builds an aggregate measure for each of the four CSR dimensions. Drawing from approaches used by previous studies (Cavaco \& Crifo, 2014; Inoue \& Lee, 2011; Lanis \& Richardson, 2012; Turban \& Greening, 1997), this paper then constructed a measure of the summed expenditure for each dimension. 


\subsubsection{CFP indicators}

CFP indicators were extracted from the CSMAR database. Following prior literature, this paper employed three CFP indicators which combines accounting and market-based perspectives. Net profit margin (NPM) (Hermawan \& Mulyawan, 2014; Kamatra \& Kartikaningdyah, 2015; Sroufe \& Gopalakrishna-Remani, 2018), returns on assets (ROA) (DixonFowler et al., 2013; Sroufe \& Gopalakrishna Remani, 2018), and Tobin's Q (Delmas et al., 2015; Inoue \& Lee, 2011; Kang et al., 2016; Surroca et al., 2010). Both NPM and ROA are common accounting-based indicators of firm profitability (Forget, 2012; Sroufe \& Gopalakrishna-Remani, 2018). Tobin's Q shows the investors' assessment of a company's capability to generate earnings in the future and indicates growth opportunities (Cavaco \& Crifo, 2014). These indicators have been widely used in research on CSR-CFP links (Cavaco \& Crifo, 2014; Inoue et al., 2013; Wang \& Qian, 2011).

\subsubsection{Control variables}

Firm characteristics are often employed as control variables (Waddock \& Graves, 1997). Following prior studies, the following firm-specific control variables are used: firm size (Wang et al., 2008; Zhao, 2012), leverage (Kao et al., 2018; Li \& Zhang, 2010; Xu \& Zeng, 2016), and asset turnover rate (Tippayawong et al., 2015). To control for possible differences in financial performance across industries and regions (Forget, 2012; Reimsbach et al., 2018), this paper added industry dummies and region dummies. Companies in this sample engage in 47 industry categories. According to Industrial Classification for National Economic Activities (GB/T4754-2017) provided by National Bureau of Statistics as well as the Amendments in the Industry Categories in the Provisions on the Division of Three Sectors (2012), these 47 industry categories can be divided into primary sector, secondary sector and tertiary sector. Considering a large quantity of data in the secondary sector, this paper further breaks it down to the manufacturing industry and other secondary industries (mining, construction, and utilities).

\subsection{Empirical model}

Consistent with previous studies (Forget, 2012; Inoue \& Lee, 2011), the model to estimate CSR-CFP link is shown as follows:

$$
\begin{aligned}
& C F P=\beta_{0}+\beta_{1} H R+\beta_{2} \text { Community }+\beta_{3} \text { Environment }+\beta_{4} B F S+\beta_{5} \text { Size }+ \\
& \beta_{6} \text { Debt }+\beta_{7} \text { TAT }+\sum_{i=1}^{m} \alpha_{i} \text { Industry }_{i}+\sum_{i=1}^{n} \gamma_{i} \text { Region }_{i},
\end{aligned}
$$

where the dependent variable CFP is measured by ROA, NPM and Tobin's Q, while independent variables including human resources, community, environment as well as business and financial stakeholders represent corporate expenditure on CSR-related management practices. Moreover, this paper included company-, industry- and region-specific control variables. The company variables consist of firm size, debt-to-asset ratio and total asset 
turnover. This research included 2 industry dummies representing 3 different industry categories (manufacturing industry, other secondary industries, and tertiary sector) and 6 region dummies representing 7 regions (east, south, north, middle, southwest, northeast, and northwest). Table 1 provides a description and measurement of the control variables and company variables. This research takes logarithmic forms to firm size, and CSR indicators to avoid potential normality issue.

Table 1. Definitions of variables (source: China Stock Market and Accounting Research (CSMAR) database)

\begin{tabular}{|l|l|l|}
\hline \multicolumn{1}{|c|}{ Variables } & \multicolumn{1}{|c|}{ Names } & \multicolumn{1}{c|}{ Definitions } \\
\hline Return on assets & ROA & $\begin{array}{l}\text { net income divided by the average total assets } \\
\text { (Wang et al., 2008; Xu \& Zeng, 2016) }\end{array}$ \\
\hline Net profit margin & NPM & $\begin{array}{l}\text { net income divided by sales revenue (Sroufe \& } \\
\text { Gopalakrishna-Remani, 2018) }\end{array}$ \\
\hline Tobin's Q & Tobin's Q & $\begin{array}{l}\text { the market value of equity and debts divided by } \\
\text { total assets (Hess et al., 2010; Ng et al., 2009; Wei } \\
\text { \& Li, 2003) }\end{array}$ \\
\hline The size of company & Size & $\begin{array}{l}\text { measured by a log of total assets (Kao et al., 2018) } \\
\text { the total liabilities divided by the total assets (Li \& } \\
\text { Zhang, 2010; Wang et al., 2008; Xu \& Zeng, 2016) }\end{array}$ \\
\hline debt-to-asset ratio & Debt & $\begin{array}{l}\text { operating revenue divided by total assets (Kao } \\
\text { et al., 2018). }\end{array}$ \\
\hline Total asset turnover & TAT &
\end{tabular}

\section{Empirical analysis}

\subsection{Diagnostic tests}

Before the estimation, this research checked the existence of outliers using studentised residuals. If the detected studentised residuals are higher than 3.29, the corresponding observations are removed before being estimated, which follows Tabachnick, Fidell, and Ullman (2007). Additionally, this study conducts heteroscedasticity tests for all the regressions by the Breush-Pagan Lagrange test, which shows that almost all the regressions have heteroscedasticity problems. This problem is addressed by the Newey-West procedure, which provides heteroscedastic and autocorrelation-consistent (HAC) standard errors. By doing so, it also avoids potential autocorrelations.

\subsection{Descriptive statistics}

Table 2 shows descriptive statistics for all the variables in different industries, including overall data, the manufacturing sector, other secondary sector and tertiary sector. Totally 568 observations are matched and merged for regressions. There are 274, 148, 139 and 7 observations for the manufacturing industry, other secondary sector, tertiary sector and primary sector respectively. This research does not include primary sector data in this study due to inadequate observations. 
Table 2. Descriptive statistics of all industries

\begin{tabular}{|c|c|c|c|c|c|}
\hline Variable & Mean & $\mathrm{SD}$ & Min & Max & $\mathrm{N}$ \\
\hline \multicolumn{6}{|l|}{ Overall } \\
\hline HR & 8.41 & 3.54 & -3.72 & 20.29 & 568 \\
\hline Community & 6.92 & 3.89 & -1.35 & 20.52 & 568 \\
\hline Environment & 9.70 & 4.19 & -4.58 & 24.13 & 567 \\
\hline BFS & 11.41 & 4.03 & 9.88 & 24.39 & 567 \\
\hline NPM & 0.11 & 0.15 & -1.19 & 0.63 & 568 \\
\hline Tobin's Q & 1.00 & 1.09 & 0.05 & 8.66 & 568 \\
\hline ROA & 0.04 & 0.06 & -0.64 & 0.23 & 568 \\
\hline Size & 24.79 & 2.35 & 20.85 & 30.66 & 568 \\
\hline Debt & 0.59 & 0.21 & 0.11 & 0.95 & 568 \\
\hline TAT & 0.66 & 0.45 & 0.02 & 2.24 & 568 \\
\hline \multicolumn{6}{|c|}{ Resource-intensive manufacturing industries } \\
\hline HR & 8.02 & 3.20 & 0.24 & 13.79 & 63 \\
\hline Community & 5.50 & 2.30 & 0.18 & 12.88 & 63 \\
\hline Environment & 9.00 & 2.27 & 5.21 & 13.34 & 63 \\
\hline BFS & 9.57 & 3.62 & -9.88 & 15.48 & 63 \\
\hline NPM & 0.07 & 0.10 & -0.13 & 0.34 & 63 \\
\hline Tobin's Q & 1.13 & 0.99 & 0.19 & 4.58 & 63 \\
\hline ROA & 0.05 & 0.06 & -0.08 & 0.19 & 63 \\
\hline Size & 24.09 & 1.32 & 21.19 & 26.18 & 63 \\
\hline Debt & 0.52 & 0.18 & 0.13 & 0.83 & 63 \\
\hline TAT & 0.89 & 0.41 & 0.32 & 2.24 & 63 \\
\hline \multicolumn{6}{|c|}{ Capital-intensive manufacturing industries } \\
\hline HR & 7.55 & 3.08 & -1.39 & 13.38 & 198 \\
\hline Community & 5.09 & 2.64 & -1.34 & 12.92 & 198 \\
\hline Environment & 7.77 & 3.23 & -4.58 & 17.53 & 198 \\
\hline BFS & 9.92 & 2.51 & 1.79 & 15.98 & 198 \\
\hline NPM & 0.06 & 0.10 & -0.65 & 0.30 & 198 \\
\hline Tobin's Q & 1.38 & 1.26 & 0.27 & 8.66 & 198 \\
\hline ROA & 0.05 & 0.06 & -0.24 & 0.22 & 198 \\
\hline Size & 23.31 & 1.38 & 20.86 & 26.96 & 198 \\
\hline Debt & 0.52 & 0.16 & 0.15 & 0.83 & 198 \\
\hline TAT & 0.84 & 0.45 & 0.11 & 2.21 & 198 \\
\hline \multicolumn{6}{|c|}{ Labour-intensive manufacturing industries } \\
\hline HR & 6.18 & 2.53 & 0.79 & 10.56 & 11 \\
\hline Community & 3.42 & 2.09 & -1.20 & 5.65 & 11 \\
\hline Environment & 7.02 & 2.35 & 2.30 & 9.15 & 11 \\
\hline BFS & 10.22 & 0.95 & 8.79 & 11.28 & 11 \\
\hline NPM & 0.04 & 0.03 & 0.01 & 0.11 & 11 \\
\hline Tobin's Q & 1.00 & 0.40 & 0.35 & 1.66 & 11 \\
\hline
\end{tabular}


End of Table 2

\begin{tabular}{|l|c|c|c|c|c|}
\hline \multicolumn{1}{|c|}{ Variable } & Mean & SD & Min & Max & N \\
\hline ROA & 0.04 & 0.02 & 0.01 & 0.07 & 11 \\
\hline Size & 23.19 & 2.00 & 20.85 & 25.55 & 11 \\
\hline Debt & 0.57 & 0.16 & 0.32 & 0.69 & 11 \\
\hline TAT & 0.83 & 0.25 & 0.41 & 1.27 & 11 \\
\hline
\end{tabular}

Other secondary sector: mining, construction, and utilities

\begin{tabular}{|l|c|c|c|c|c|}
\hline HR & 9.53 & 3.59 & -2.23 & 20.29 & 148 \\
\hline Community & 8.29 & 3.49 & -1.31 & 16.63 & 148 \\
\hline Environment & 9.72 & 2.63 & 1.79 & 14.82 & 148 \\
\hline BFS & 11.21 & 2.92 & 1.39 & 18.26 & 148 \\
\hline NPM & 0.08 & 0.14 & -1.19 & 0.33 & 148 \\
\hline Tobin's Q & 0.79 & 0.74 & 0.10 & 5.71 & 148 \\
\hline ROA & 0.05 & 0.08 & -0.64 & 0.23 & 148 \\
\hline Size & 25.29 & 1.66 & 21.23 & 28.04 & 148 \\
\hline Debt & 0.57 & 0.18 & 0.11 & 0.89 & 148 \\
\hline TAT & 0.63 & 0.29 & 0.10 & 1.94 & 148 \\
\hline
\end{tabular}

Tertiary sector

\begin{tabular}{|l|c|c|c|c|c|}
\hline HR & 8.89 & 3.94 & -3.71 & 15.64 & 139 \\
\hline Community & 9.17 & 4.66 & -0.92 & 20.52 & 139 \\
\hline Environment & 13.20 & 5.29 & 3.81 & 24.12 & 139 \\
\hline BFS & 14.90 & 4.95 & 2.30 & 24.39 & 139 \\
\hline NPM & 0.25 & 0.18 & -0.13 & 0.63 & 139 \\
\hline Tobin's Q & 0.54 & 1.02 & 0.05 & 7.61 & 139 \\
\hline ROA & 0.03 & 0.02 & -0.06 & 0.10 & 139 \\
\hline Size & 26.95 & 2.65 & 21.41 & 30.66 & 139 \\
\hline Debt & 0.75 & 0.23 & 0.12 & 0.95 & 139 \\
\hline TAT & 0.29 & 0.42 & 0.02 & 2.16 & 139 \\
\hline
\end{tabular}

As the manufacturing industry has the most of observations, this research further breaks it down to resource-intensive (63 observations), capital- intensive (198 observations) and labour-intensive manufacturing industries (11 observations) based on the Standard International Trade Classification (SITC) provided by United Nations. However, the number of observations in the labour-intensive industry is too small to produce any regression result.

\subsection{Overall regression}

Table 3 presents the regression results for the overall data, which shows community, environment and business and financial stakeholders are highly and positively significant in explaining NPM. It implies that if firms invest money in these aspects, they would benefit in 
higher net profit generated as a percentage of revenue, which is similar to the ROA equation. However, in terms of long-term performance (Tobin's Q), only the investment spent on community and business and financial stakeholders are positively significant, which means that money spent on employees and environment does not increase Tobin's Q. Most of the control variables are significant except size and TAT in the NPM and Tobin's Q equation respectively. Table 3 shows that $1 \%$ growth of expenditure in community, environment, and business and financial stakeholders cause $0.38 \%, 0.84 \%$, and $0.75 \%$ rise in NPM while contributing to $0.18 \%, 0.09 \%$, and $0.14 \%$ increase in ROA. With $1 \%$ rise in the spending in community and BFS, Tobin's Q can increase by 1.37 and 2.39 respectively. Hence, H2, H3 and H4 are supported in overall data. Most of the industry and region dummy variables are significant. The overall R-squared is between $40 \%$ and $60 \%$, compared with $18 \%$ in the study of Inoue and Lee (2011) and 20-49\% in the research done by Cavaco and Crifo (2014). This implies the model can explain the data reasonably well.

Table $3 .^{1}$ Overall data

\begin{tabular}{|l|c|c|c|c|c|c|}
\hline \multirow{2}{*}{ Variable } & \multicolumn{2}{|c|}{ NPM } & \multicolumn{2}{c|}{ ROA } & \multicolumn{2}{c|}{ Tobin's Q } \\
\cline { 2 - 7 } & Coef. & Std. Err. & Coef. & Std. Err. & Coef. & Std. Err. \\
\hline HR & -0.1690 & 0.1234 & 0.0053 & 0.0454 & 0.15839 & 0.7023 \\
\hline Community & $0.3835^{* * *}$ & 0.1435 & $0.1762^{* * *}$ & 0.0481 & $1.3728^{*}$ & 0.7259 \\
\hline Environment & $0.8423^{* * *}$ & 0.1657 & $0.0934^{*}$ & 0.0568 & -0.8452 & 1.1214 \\
\hline BFS & $0.7453^{* * *}$ & 0.1392 & $0.1400^{* * *}$ & 0.0428 & $2.3915^{* * *}$ & 0.7577 \\
\hline Size & 0.1083 & 0.4381 & $0.1728^{* * *}$ & 0.1823 & $-14.3410^{* * *}$ & 2.5035 \\
\hline Debt & $-13.883^{* * *}$ & 2.9307 & $-16.429^{* * *}$ & 1.2949 & $-175.499^{* * *}$ & 19.708 \\
\hline TAT & $-9.7352^{* * *}$ & 0.9880 & $1.9160^{* * *}$ & 0.3910 & -2.8961 & 6.0200 \\
\hline R-squared & 57.31 & & 40.94 & & 55.54 & \\
\hline
\end{tabular}

\subsection{Regressions across industries}

\subsubsection{Secondary sector: manufacturing}

Table 4 shows the regression of the resource-intensive manufacturing industries. The expenditure on human resources is negatively correlated with firm performance. Therefore, $\mathrm{H} 1$ is not supported in resource-intensive industries. Community and business and financial stakeholders positively affect ROA and Tobin's Q respectively, which supports $\mathrm{H} 2$ and $\mathrm{H} 4$. With an extra one percent more HR expenses, NPM, ROA and Tobin's Q decline by $0.51 \%, 0.41 \%$ and 6.15 respectively. If there is $1 \%$ increase in the community expenses, ROA will rise by $0.55 \%$.

Looking at the capital-intensive manufacturing industries in Table 5, spending in human resources is all positively significant in NPM, ROA and Tobin's Q, while environment expenditure is negatively in these equations. Hence, $\mathrm{H} 1$ is supported while $\mathrm{H} 3$ is not proven in capital-intensive manufacturing industries. Additionally, the spending on business and

\footnotetext{
1 Please note that all the numbers in the regressions are multiplied by $100 .^{*}$, ${ }^{* *}$, and ${ }^{* * *}$ represent $10 \%, 5 \%$ and $1 \%$ significance level in this paper.
} 
financial stakeholders is negatively significant in explaining Tobin's Q, not supporting H4. For the capital-intensive manufacturing industries, with an extra $1 \%$ more HR expenses, NPM, ROA and Tobin's Q increase by $0.37 \%, 0.27 \%$ and 4.54 respectively. If there is $1 \%$ increase in the environment expenses, NPM, ROA and Tobin's Q drop by $0.39 \%, 0.20 \%$ and 7.14 respectively. Tobin's Q drops by 2.66 with one percent more expenditure in BFS.

Table 4. Resource-intensive manufacturing industries

\begin{tabular}{|l|c|c|c|c|c|c|}
\hline \multirow{2}{*}{ Variable } & \multicolumn{2}{|c|}{ NPM } & \multicolumn{2}{c|}{ ROA } & \multicolumn{2}{c|}{ Tobin's Q } \\
\cline { 2 - 7 } & Coef. & Std. Err. & Coef. & Std. Err. & Coef. & Std. Err. \\
\hline HR & $-0.5125^{\star}$ & 0.2724 & $-0.4078^{\star}$ & 0.2346 & $-6.1486^{* *}$ & 2.6439 \\
\hline Community & 0.4903 & 0.4155 & $0.5530^{*}$ & 0.3093 & -1.0545 & 2.3303 \\
\hline Environment & -0.2837 & 0.3204 & -0.2609 & 0.2619 & -1.4624 & 2.3204 \\
\hline BFS & 0.2014 & 0.1318 & 0.3392 & 0.2242 & $11.5466^{* * *}$ & 4.1797 \\
\hline Size & -0.4432 & 0.7599 & -0.9049 & 0.6303 & $-35.2716^{* * *}$ & 8.4679 \\
\hline Debt & -15.3649 & $4.6556^{* * *}$ & $-13.9135^{* * *}$ & 4.2823 & $-296.2026^{* * *}$ & 34.6159 \\
\hline TAT & 1.6947 & 2.172 & $4.7782^{*}$ & 2.5129 & 65.6229 & 22.5573 \\
\hline R-squared & 84.19 & & 67.37 & & 87.30 & \\
\hline
\end{tabular}

Table 5. Capital-intensive manufacturing industries

\begin{tabular}{|l|c|c|c|c|c|c|}
\hline \multirow{2}{*}{ Variable } & \multicolumn{2}{|c|}{ NPM } & \multicolumn{2}{c|}{ ROA } & \multicolumn{2}{c|}{ Tobin's Q } \\
\cline { 2 - 7 } & Coef. & Std. Err. & Coef. & Std. Err. & Coef. & Std. Err. \\
\hline HR & $0.3705^{*}$ & 0.1414 & $0.2713^{*}$ & 0.1038 & $4.5427^{* *}$ & 1.8047 \\
\hline Community & 0.3591 & 0.3297 & 0.1178 & 0.1323 & -0.3774 & 2.1703 \\
\hline Environment & $-0.3870^{* * *}$ & 0.1469 & $-0.1994^{*}$ & 0.1218 & $-7.1366^{* *}$ & 2.3333 \\
\hline BFS & 0.1029 & 0.1631 & -0.1101 & 0.1051 & $-2.6621^{\star}$ & 1.5708 \\
\hline Size & $1.7346^{* * *}$ & 0.5736 & $1.2607^{* * *}$ & 0.4181 & $-11.2102^{\star}$ & 5.9849 \\
\hline Debt & $-36.8231^{* * *}$ & 4.6974 & $-25.8925^{* * *}$ & 2.5262 & $-292.5646^{* * *}$ & 52.3445 \\
\hline TAT & $-2.6705^{* * *}$ & 0.9547 & $3.1110^{* * *}$ & 0.6799 & $21.3531^{* *}$ & 8.9210 \\
\hline R-squared & 56.27 & & 54.07 & & 67.19 & \\
\hline
\end{tabular}

\subsubsection{Other secondary sector}

Regarding the other secondary sector, such as mining, construction, and utilities, this research finds that community expenditure has a positive impact on firm performance (see Table 6), which supports $\mathrm{H} 2$. With $1 \%$ rise in community expenditure in these secondary sectors, NPM, ROA and Tobin's Q increase by $0.32 \%, 0.20 \%$ and 1.62 respectively. All the other CSR dimensions are not significant except the environment in the Tobin's $\mathrm{Q}$ equation, thus $\mathrm{H} 3$ is supported. If firms spend $1 \%$ more on environment, they would benefit in getting 3.14 higher Tobin's Q. Firm will get benefits in a longer term if they invest more in environment in the mining, construction and utility industries. The control variables are all significant except size in NPM and ROA equation with R-squared between $40 \%$ and $57 \%$. 
Table 6. Other secondary sector

\begin{tabular}{|l|c|c|c|c|c|c|}
\hline \multirow{2}{*}{ Variable } & \multicolumn{2}{|c|}{ NPM } & \multicolumn{2}{c|}{ ROA } & \multicolumn{2}{c|}{ Tobin's Q } \\
\cline { 2 - 7 } & Coef. & Std. Err. & Coef. & Std. Err. & Coef. & Std. Err. \\
\hline HR & 0.2537 & 0.1790 & 0.0256 & 0.1105 & 0.5521 & 1.3832 \\
\hline Community & $0.3187^{\star *}$ & 0.1546 & $0.1964^{* *}$ & 0.0872 & $1.6160^{*}$ & 0.8497 \\
\hline Environment & 0.1245 & 0.2181 & 0.1799 & 0.1325 & $3.1442^{\star}$ & 1.6311 \\
\hline BFS & 0.1391 & 0.2808 & 0.1175 & 0.0882 & 0.0321 & 0.9818 \\
\hline Size & 0.2022 & 0.5772 & -0.4535 & 0.3132 & $-23.0062^{\star * *}$ & 3.9898 \\
\hline Debt & $-30.126^{* * *}$ & 4.0602 & $-16.9737^{* * *}$ & 2.2122 & $-133.530^{* * *}$ & 23.4251 \\
\hline TAT & -0.2261 & 2.3946 & $5.7748^{* * *}$ & 1.4035 & $40.0682^{\star * *}$ & 12.0020 \\
\hline R-squared & 47.13 & & 56.20 & & 54.32 & \\
\hline
\end{tabular}

\subsubsection{Tertiary sector}

In terms of the tertiary sector in Table 7, the expenditures in human resources, environment and business and financial stakeholders are significant in describing NPM, while only environment is significant in explaining ROA. However, no CSR dimensions are significant in Tobin's Q equation in this sector. Environment and business and financial stakeholders are positively related to NPM, causing $1.47 \%$ and $0.82 \%$ rise in NPM respectively. $\mathrm{H} 3$ and $\mathrm{H} 4$ are supported. If firms spend $1 \%$ more in human resources, it is likely to create a fall of $0.78 \%$ in NPM. Additionally, if firms spend $1 \%$ more percent in the environment in the tertiary sector, it would create extra $0.08 \%$ of ROA at the same time.

Table 7. Tertiary sector

\begin{tabular}{|l|c|c|c|c|c|c|}
\hline \multirow{2}{*}{ Variable } & \multicolumn{2}{|c|}{ NPM } & \multicolumn{2}{c|}{ ROA } & \multicolumn{2}{c|}{ Tobin's Q } \\
\cline { 2 - 7 } & Coef. & Std. Err. & Coef. & Std. Err. & Coef. & Std. Err. \\
\hline HR & $-0.7750^{* * *}$ & 0.2440 & 0.0067 & 0.0243 & 0.5787 & 0.7590 \\
\hline Community & 0.1279 & 0.2479 & 0.0297 & 0.0337 & 0.1614 & 0.7165 \\
\hline Environment & $1.4731^{* * *}$ & 0.3742 & $0.0761^{\star *}$ & 0.0384 & -0.3256 & 1.0140 \\
\hline BFS & $0.8222^{* * *}$ & 0.2823 & -0.0086 & 0.0321 & 1.0486 & 0.7790 \\
\hline Size & $-2.9732^{\star * *}$ & 1.1068 & $-0.6721^{* * *}$ & 0.1802 & $-12.7101^{\star * *}$ & 3.2396 \\
\hline Debt & $16.3017^{*}$ & 6.2195 & -1.5441 & 1.5900 & $-61.7863^{\star *}$ & 27.6117 \\
\hline TAT & $-21.5088^{* * *}$ & 4.0471 & 0.4211 & 0.4641 & 3.0471 & 13.0342 \\
\hline R-squared & 65.46 & & 62.36 & & 67.19 & \\
\hline
\end{tabular}

\subsection{Discussion}

The research results show that the CSR-CFP link in Chinese publicly listed firms is positive on the whole, which is consistent with prior empirical studies targeting at developed countries (Kao et al., 2018). However, the financial impacts of CSR dimensions are contextual, varying from sector to sector (see Table 8). 
Table 8. Summary of all the regressions

\begin{tabular}{|c|c|c|c|c|c|}
\hline Sector & $\begin{array}{l}\text { Dependent } \\
\text { variables }\end{array}$ & HR & Community & Environment & BFS \\
\hline \multirow{3}{*}{ Overall } & NPM & & + & + & + \\
\hline & ROA & & + & + & + \\
\hline & Tobin's Q & & + & & + \\
\hline \multirow{3}{*}{$\begin{array}{l}\text { Resource-intensive } \\
\text { manufacturing } \\
\text { industries }\end{array}$} & NPM & - & & & \\
\hline & ROA & - & + & & \\
\hline & Tobin's Q & - & & & + \\
\hline \multirow{3}{*}{$\begin{array}{l}\text { Capital-intensive } \\
\text { manufacturing } \\
\text { industries }\end{array}$} & NPM & + & & - & \\
\hline & ROA & + & & - & \\
\hline & Tobin's Q & + & & - & - \\
\hline \multirow{3}{*}{$\begin{array}{l}\text { Other secondary } \\
\text { sector }\end{array}$} & NPM & & + & & \\
\hline & ROA & & + & & \\
\hline & Tobin's Q & & + & + & \\
\hline \multirow{3}{*}{ Tertiary sector } & NPM & - & & + & + \\
\hline & ROA & - & & + & \\
\hline & Tobin's Q & & & & \\
\hline
\end{tabular}

Regarding human resources, this research finds the impact of HR on CFP is negative in the tertiary sector and resource-intensive manufacturing industries. The results differ from the previous study done by Berman, Wicks, Kotha, and Jones (1999) which indicates a positive relationship between human resources and firm performance. It also contradicts with the result concluded by Bravo, Buil, de Chernatony, and Martínez (2017), who use bank employees in the United Kingdom as sample data, and find a positive perception of CSR initiatives among employees can enhance organisational commitment. The improved employeeemployer relationship can thus contribute to the financial performance of a firm. The data from Chinese firms produce a different result. This may happen because human resources are the key resources for tertiary sector in China. Firms spend a significant amount of money on training employees with the necessary skills, but employees may leave the company after accumulating enough experience and skills. High employee turnover will cause more recruiting and training (Hancock et al., 2013), which can lead to poor short-term profitability. For resource-intensive manufacturing industries, raw materials are viewed as crucial. More investment in HR would take away company resources and increase cost, thus undermining financial performance in both the short and long run. However, a positive relationship between human resources and firm performance is found in capital-intensive manufacturing industries. In China, these industries are where the capital, technology and talented people are gathered. Skilled professionals have higher requirements for human resources policies. Improvement of workplace conditions, career development and training, equity incentive programs, can attract motivated employees, reduce employee turnover (Portney, 2008), improve productivity (Berman et al., 1999), encourage extra efforts made by employees (Khattak et al., 2019) and ensure firm performance (Brekke \& Nyborg, 2008). 
CSR investments in the community are positively related to financial performance in resource-intensive industries and other secondary sector (mining, construction, and utilities). These industries create many jobs opportunities but may also cause environmental damage. Companies in these industries are faced with more public claims for the environment and social concern (Jiang \& Wong, 2016). In general, traditional Chinese values including Buddhism, Taoism and Confucianism are ingrained in the minds of Chinese people, teaching them to be benevolent, and compassionate to others (Wang \& Qian, 2011). Thus, Chinese consumers commend and reward firms that contribute generously, which has a positive impact on corporate financial performance (Wang \& Qian, 2011). However, this is not the case in the study conducted by (Inoue \& Lee, 2011). The sample data of their research use the KLD STATS database consisting of annual ratings of around 3600 publicly traded U.S. companies in tourism-related industries. Inoue and Lee (2011) find that CSR investment in the community is negatively related to short-term profitability for airline firms, because there is indirect relationship between airline firms and community, expenditure incurred outweighs gains from community engagement.

In terms of environment, a negative link is found in the capital-intensive manufacturing industries for both short profitability and long-term performance. This is likely because the development of these industries relies heavily on capital, entailing a large amount of input. With low resource exchanges (Kacperczyk, 2009; Mattingly \& Berman, 2006), CSR efforts in the environment are more likely to be driven by normative expectation than instrumental goals (Donaldson \& Preston, 1995), hardly generating any financial gains (Kacperczyk, 2009). On the other hand, environment expenditure affects firm performance positively in other secondary sector in the long run and in the tertiary sector in the short term. This may be attributed to the fact that the Chinese government has attached great importance to environmental protection in recent decades. The government can provide tax incentives (Yin \& Zhang, 2012) and other financial incentives to deliver corporate net benefits (Yin, 2017) to reward firms making efforts to protect the environment. The effect of government compensation can be noticeable in these industries, but negligible in industries requiring huge capital investment.

Compared with the mixed results produced from data in China, Daszynska-Zygadlo et al. (2016) reveal the negative role of environment dimension from global data. Based on 2428 companies around the world, they find environmental efforts negatively affect Tobin's Q in 8 sectors, and Price/Earnings ratio in 7 sectors (materials, consumer discretionary, financials, healthcare, industrials, information technology, and utilities). One possible reason is provided by Derwall, Guenster, Bauer, and Koedijk (2005) and Semenova and Hassel (2008), it is hard for environmentally sensitive industries to enjoy positive CSR impacts because of the higher cost of environmental performance.

Moreover, firms, in general, could generate benefits in spending more in business and financial stakeholders, because meeting the expectations of stakeholders can foster a favourable business environment and help firms to accomplish excellent financial performance. However, a negative relationship is found in the capital-intensive manufacturing industries in the long run. This may also because the growth of these industries depends heavily on capital. Expenditure in business and financial stakeholders may increase cost and affect investors' evaluation of future profitability. 
Certain CSR dimensions affect firm performance in the short run but not in the long run, such as HR in the tertiary sector, the environment in the tertiary sector, and BFS in the tertiary sector. This may be because Tobin's Q can be more responsive to macroeconomic changes, government policies or to industry-related factors, such as price fluctuation caused by changes in industry demand and supply (Cavaco \& Crifo, 2014). However, the case might be a bit different in China and other emerging markets. Private firms abound in the tertiary sector. The majority of private companies in emerging economies are owned or run by family members (Fan et al., 2011). This is also the case in China where over three-quarters of China's private firms is family-owned (Yang, 2011). Different from family businesses in the U.S. and the U.K with diffused ownership and professional leadership after being publicly listed, it is common for emerging markets firms to still have highlyconcentrated ownership and employ non-professional family members as managers (Fan et al., 2011). Under this circumstance, investment decisions might be made arbitrarily by the family business owner, making it hard for investors to have a positive assessment of a firm's ability to yield earnings in the future.

In some cases, CSR affects Tobin's Q but has no effects on short-term accounting measures, such as the environment in the other secondary sector and BFS in the resource-intensive and capital-intensive manufacturing industries. This is likely because carrying out CSR programs shows a firm's care for society. The strong influence of traditional values spur Chinese stakeholders of the firm to welcome and reward generous firms (Wang \& Qian, 2011). CSR efforts can improve corporate reputation and image, thus boosting investors' confidence about a firm's future profitability despite no significant financial impacts on shortterm profitability.

\section{Conclusions}

This research aims to investigate the heterogeneity of CSR's effect on corporate financial performance across industries. This study employs four dimensions including human resources, community, environment, as well as business and financial stakeholders to represent CSR and examine the effect of each CSR dimension on a firm's short-term profitability and long-term marketed-based profitability across industries, including manufacturing industry (resourceintensive, capital-intensive and labour-intensive industries), other secondary sector (mining, construction, utilities) and tertiary sector.

Findings from this study show that CSR has a positive impact on CFP as a whole, which is consistent with the research done in developed countries. However, the research also reveals that various CSR dimensions have different influence on CFP across analysed industries as the research context is China, an emerging market with different cultural context and various sectors. Therefore, the paper can conclude that CSR's influence on CFP is of context related. The findings confirm that CSR-CFP link in China is contingent upon which CSR dimension is considered and which industry is examined. Therefore, this research suggests managers in different sectors should make CSR decisions carefully because each industry can benefit or suffer from certain CSR efforts, and some sectors remain unaffected by CSR investment. 
Based on research results, this research can draw a number of practical implications to help managers in China to invest in CSR activities which can benefit firm performance. Since capital-intensive manufacturing industries react positively to human resources initiatives and negatively to environment efforts, firms in these industries can conduct CSR activities around human resources rather environment to deliver a good financial outcome. Investments can be made to improve workplace conditions, social security coverage, payment systems, equity incentive programs, employee participation, and career development and training. Companies in resource-intensive manufacturing industries can make CSR efforts in the community for the short-term benefit and improve relations with business and financial stakeholders for long-term performance. However, they need to be careful when investing in human resources, given the negative impacts on financial performance. The other secondary sector, such as mining, construction and utilities is sensitive to community actions, firms in this sector can focus the CSR efforts on community issues. Engaging in community campaigns and volunteer programs, donating to charity can help firms build harmonious relationship with the community and benefit both the short-term and long-term profitability. Additionally, firms in the tertiary sector seeking short-term profitability should make CSR investments in environment, such as providing eco-friendly services, holding training on green development, recycling, and adopting paper-free office systems. Caution should be made when investing in human resources in the tertiary sector as results of this research suggest negative financial impacts.

The limitation of this research is that it mainly focuses on CSR dimensions which represent stakeholders without considering human rights or diversity issues. Future research can include these dimensions to explore the impacts on financial performance in Chinese firms. Secondly, this research only chooses CSR activities listing annual corporate expenditure to measure CSR efforts. Non-financial CSR activities take different forms and vary across companies. Future research can compare and contrast voluntary programs conducted by different companies and assess the effects on firm performance. Moreover, this sample only includes publicly listed companies. Some companies which are not listed also have invested in CSR significantly but not presented in the data. Therefore, further research may explore ways that listed and non-listed firms choose to conduct CSR activities. Finally, the way that CSR expenditure is reflected in the accounting statements has different implications on performance. If the CSR expenditure is counted in the income statement, the profit margin will be smaller. While if it is counted in the balance sheet, the profit margin will be higher. The link between CSR expenditure and firm's performance can be better understood if this paper could find out the accounting practice about how CSR expenditure is counted. However, there is no unified way to categorise all the CSR items in the accounting statement. For example, donations to the community (community) are counted in the non-operating expenses in the income statement, while investment in the equipment to reduce emission is counted in the capital expenditure in the balance sheet. Therefore, the analysis is limited in identifying this differentiation. However, the paper does provide a platform for future research to explore how this differentiation affects financial ratios in CSR-CFP link and possible to analyze the link with each individual sector in China and other emerging markets. 


\section{Acknowledgements}

We are grateful to China Stock Market \& Accounting Research (CSMAR) Database for the generosity in providing the report they produce. We greatly appreciate the honourable reviewers and the editors of the Journal of Business Economics and Management for insightful comments and useful suggestions to help us improve the quality of the research. We also would like to thank China Scholarship Council, College of International Studies of Sichuan University, and Nottingham Business School of Nottingham Trent University for support.

\section{Funding}

This work was supported by the China Scholarship Council under Grant [number 201806240014].

\section{Disclosure statement}

Authors do not have any competing financial, professional, or personal interests from other parties

\section{References}

Albuquerque, R., Koskinen, Y., \& Zhang, C. (2019). Corporate social responsibility and firm risk: Theory and empirical evidence. Management Science, 65(10), 4451-4469. https://doi.org/10.1287/mnsc.2018.3043

Alshehhi, A., Nobanee, H., \& Khare, N. (2018). The impact of sustainability practices on corporate financial performance: Literature trends and future research potential. Sustainability, 10(2), 1-25. https://doi.org/10.3390/su10020494

Avetisyan, E., \& Ferrary, M. (2013). Dynamics of stakeholders' implications in the institutionalization of the CSR field in France and in the United States. Journal of Business Ethics, 115(1), 115-133. https://doi.org/10.1007/s10551-012-1386-3

Barla, P. (2007). ISO 14001 certification and environmental performance in Quebec's pulp and paper industry. Journal of Environmental Economics and Management, 53(3), 291-306. https://doi.org/10.1016/j.jeem.2006.10.004

Berman, S. L., Wicks, A. C., Kotha, S., \& Jones, T. M. (1999). Does stakeholder orientation matter? The relationship between stakeholder management models and firm financial performance. Academy of Management Journal, 42(5), 488-506. https://doi.org/10.5465/256972

Bhattacharya, A., Good, V., Sardashti, H., \& Peloza, J. (2020). Beyond warm glow: The Risk-mitigating effect of Corporate Social Responsibility (CSR). Journal of Business Ethics, 161, 1-20. https://doi.org/10.1007/s10551-020-04445-0

Brammer, S., Brooks, C., \& Pavelin, S. (2006). Corporate social performance and stock returns: UK evidence from disaggregate measures. Financial Management, 35(3), 97-116. https://doi.org/10.1111/j.1755-053X.2006.tb00149.x

Bravo, R., Buil, I., de Chernatony, L., \& Martínez, E. (2017). Brand Identity management and Corporate Social Responsibility: An analysis from employees' perspective in the banking sector. Journal of Business Economics and Management, 18(2), 241-257.

https://doi.org/10.3846/16111699.2016.1209785 
Brekke, K. A., \& Nyborg, K. (2008). Attracting responsible employees: Green production as labor market screening. Resource and Energy Economics, 30(4), 509-526.

https://doi.org/10.1016/j.reseneeco.2008.05.001

Carroll, A. B. (1991). The pyramid of corporate social responsibility: Toward the moral management of organizational stakeholders. Business Horizons, 34(4), 39-48.

https://doi.org/10.1016/0007-6813(91)90005-G

Cavaco, S., \& Crifo, P. (2014). CSR and financial performance: complementarity between environmental, social and business behaviours. Applied Economics, 46(27), 3323-3338.

https://doi.org/10.1080/00036846.2014.927572

Chatterji, A. K., Levine, D. I., \& Toffel, M. W. (2009). How well do social ratings actually measure corporate social responsibility? Journal of Economics \& Management Strategy, 18(1), 125-169. https://doi.org/10.1111/j.1530-9134.2009.00210.x

Cheung, Y.-L., Jiang, K., \& Tan, W. (2012). “Doing-good” and “doing-well” in Chinese publicly listed firms. China Economic Review, 23(4), 776-785. https://doi.org/10.1016/j.chieco.2012.03.013

Clarkson, M. E. (1995). A stakeholder framework for analyzing and evaluating corporate social performance. Academy of Management Review, 20(1), 92-117. https://doi.org/10.5465/amr.1995.9503271994

Contini, M., Annunziata, E., Rizzi, F., \& Frey, M. (2020). Exploring the influence of Corporate Social Responsibility (CSR) domains on consumers' loyalty: An experiment in BRICS countries. Journal of Cleaner Production, 247, 119-158. https://doi.org/10.1016/j.jclepro.2019.119158

Crifo, P., Diaye, M. A., \& Pekovic, S. (2016). CSR related management practices and firm performance: An empirical analysis of the quantity-quality trade-off on French data. International Journal of Production Economics, 171(Part 3), 405-416. https://doi.org/10.1016/j.ijpe.2014.12.019

Daszynska-Zygadlo, K., Slonski, T., \& Zawadzki, B. (2016). The market value of CSR performance across sectors. Engineering Economics, 27(2), 230-238. https://doi.org/10.5755/j01.ee.27.2.13480

Delmas, M. A., Nairn-Birch, N., \& Lim, J. (2015). Dynamics of environmental and financial performance: The case of greenhouse gas emissions. Organization \& Environment, 28(4), 374-393. https://doi.org/10.1177/1086026615620238

Derwall, J., Guenster, N., Bauer, R., \& Koedijk, K. (2005). The eco-efficiency premium puzzle. Financial Analysts Journal, 61(2), 51-63. https://doi.org/10.2469/faj.v61.n2.2716

Dixon-Fowler, H. R., Slater, D. J., Johnson, J. L., Ellstrand, A. E., \& Romi, A. M. (2013). Beyond "does it pay to be green?" A meta-analysis of moderators of the CEP-CFP relationship. Journal of Business Ethics, 112(2), 353-366. https://doi.org/10.1007/s10551-012-1268-8

Donaldson, T., \& Preston, L. E. (1995). The stakeholder theory of the corporation: Concepts, evidence, and implications. Academy of Management Review, 20(1), 65-91. https://doi.org/10.5465/amr.1995.9503271992

Falck, O., \& Heblich, S. (2007). Corporate social responsibility: Doing well by doing good. Business Horizons, 50(3), 247-254. https://doi.org/10.1016/j.bushor.2006.12.002

Fan, J. P., Wei, K. J., \& Xu, X. (2011). Corporate finance and governance in emerging markets: A selective review and an agenda for future research. Journal of Corporate Finance, 17(2), 207-214. https://doi.org/10.1016/j.jcorpfin.2010.12.001

Filbeck, G., \& Gorman, R. F. (2004). The relationship between the environmental and financial performance of public utilities. Environmental and Resource Economics, 29(2), 137-157. https://doi.org/10.1023/B:EARE.0000044602.86367.ff

Flammer, C., Hong, B., \& Minor, D. (2019). Corporate governance and the rise of integrating corporate social responsibility criteria in executive compensation: Effectiveness and implications for firm outcomes. Strategic Management Journal, 40(7), 1097-1122. https://doi.org/10.1002/smj.3018

Forget, V. (2012). Doing well and doing good: A multi-dimensional puzzle. https://hal.archives-ouvertes.fr/hal-00672037/document 
Freeman, R. E. (1984). Strategic management: A stakeholder approach. Pitman.

Fukukawa, K., \& Moon, J. (2004). A Japanese model of corporate social responsibility? A study of website reporting. Journal of Corporate Citizenship, 16, 45-59.

Galema, R., Plantinga, A., \& Scholtens, B. (2008). The stocks at stake: Return and risk in socially responsible investment. Journal of Banking \& Finance, 32(12), 2646-2654. https://doi.org/10.1016/j.jbankfin.2008.06.002

Gimenez, C., Sierra, V., \& Rodon, J. (2012). Sustainable operations: Their impact on the triple bottom line. International Journal of Production Economics, 140(1), 149-159. https://doi.org/10.1016/j.ijpe.2012.01.035

Girerd-Potin, I., Jimenez-Garcès, S., \& Louvet, P. (2014). Which dimensions of social responsibility concern financial investors? Journal of Business Ethics, 121(4), 559-576. https://doi.org/10.1007/s10551-013-1731-1

Godfrey, P. C., \& Hatch, N. W. (2007). Researching corporate social responsibility: An agenda for the 21st century. Journal of Business Ethics, 70(1), 87-98. https://doi.org/10.1007/s10551-006-9080-y

Hancock, J. I., Allen, D. G., Bosco, F. A., McDaniel, K. R., \& Pierce, C. A. (2013). Meta-analytic review of employee turnover as a predictor of firm performance. Journal of Management, 39(3), 573-603. https://doi.org/10.1177/0149206311424943

Hermawan, M., \& Mulyawan, S. (2014). Profitability and Corporate Social Responsibility: An analysis of Indonesia's Listed company. Asia Pacific Journal of Accounting and Finance, 3(1), 15-31.

Hess, K., Gunasekarage, A., \& Hovey, M. (2010). State-dominant and non-state-dominant ownership concentration and firm performance: Evidence from China. International Journal of Managerial Finance, 6(4), 264-289. https://doi.org/10.1108/17439131011074440

Hillman, A. J., \& Keim, G. D. (2001). Shareholder value, stakeholder management, and social issues: what's the bottom line? Strategic Management Journal, 22(2), 125-139. https://doi.org/10.1002/1097-0266(200101)22:2<125::AID-SMJ150>3.0.CO;2-H

Hoepner, A. G., \& Yu, P. S. (2010). Corporate social responsibility across industries: When can who do well by doing good? http://ssrn.com/abstract $=1284703$

Huselid, M. A. (1995). The impact of human resource management practices on turnover, productivity, and corporate financial performance. Academy of Management Journal, 38(3), 635-672. https://doi.org/10.2307/256741

Inoue, Y., Iii, J. E. M., \& Kent, A. (2013). Enhancing the benefits of professional sport philanthropy: The roles of corporate ability and communication strategies. Sport Management Review, 16(16), 314-325. https://doi.org/10.1016/j.smr.2012.10.003

Inoue, Y., \& Lee, S. (2011). Effects of different dimensions of corporate social responsibility on corporate financial performance in tourism-related industries. Tourism Management, 32(4), 790-804. https://doi.org/10.1016/j.tourman.2010.06.019

Jiang, W., \& Wong, J. K. (2016). Key activity areas of corporate social responsibility (CSR) in the construction industry: A study of China. Journal of Cleaner Production, 113, 850-860. https://doi.org/10.1016/j.jclepro.2015.10.093

Johnson, R. A., \& Greening, D. W. (1999). The effects of corporate governance and institutional ownership types on corporate social performance. Academy of Management Journal, 42(5), 564-576. https://doi.org/10.2307/256977

Kacperczyk, A. (2009). With greater power comes greater responsibility? Takeover protection and corporate attention to stakeholders. Strategic Management Journal, 30(3), 261-285. https://doi.org/10.1002/smj.733

Khattak, S. I., Jiang, Q., Li, H., \& Zhang, X. (2019). Corporate social responsibility (CSR) and leadership: Validation of a multi-factor framework in the United Kingdom (UK). Journal of Business Economics and Management, 20(4), 754-776. https://doi.org/10.3846/jbem.2019.9852 
Kamatra, N., \& Kartikaningdyah, E. (2015). Effect corporate social responsibility on financial performance. International Journal of Economics and Financial Issues, 5(1S), 157-164.

Kang, C., Germann, F., \& Grewal, R. (2016). Washing away your sins? Corporate social responsibility, corporate social irresponsibility, and firm performance. Journal of Marketing, 80(2), 59-79. https://doi.org/10.1509/jm.15.0324

Kao, E. H., Yeh, C. C., Wang, L. H., \& Fung, H. G. (2018). The relationship between CSR and performance: Evidence in China. Pacific-Basin Finance Journal, 51, 155-170. https://doi.org/10.1016/j.pacfin.2018.04.006

Lanis, R., \& Richardson, G. (2012). Corporate social responsibility and tax aggressiveness: An empirical analysis. Journal of Accounting and Public Policy, 31(1), 86-108. https://doi.org/10.1016/j.jaccpubpol.2011.10.006

Lee, M. J., \& Jang, S. S. (2007). Market diversification and financial performance and stability: A study of hotel companies. International Journal of Hospitality Management, 26(2), 362-375. https://doi.org/10.1016/j.ijhm.2006.02.002

Li, W., \& Zhang, R. (2010). Corporate social responsibility, ownership structure, and political interference: Evidence from China. Journal of Business Ethics, 96(4), 631-645. https://doi.org/10.1007/s10551-010-0488-Z

Luo, X., \& Bhattacharya, C. B. (2006). Corporate social responsibility, customer satisfaction, and market value. Journal of Marketing, 70(4), 1-18. https://doi.org/10.1509/jmkg.70.4.001

Maignan, I., \& Ralston, D. A. (2002). Corporate Social Responsibility in Europe and the U.S.: Insights from businesses' self-presentations. Journal of International Business Studies, 33(3), 497-514. https://doi.org/10.1057/palgrave.jibs.8491028

Mattingly, J. E., \& Berman, S. L. (2006). Measurement of corporate social action: Discovering taxonomy in the Kinder Lydenburg Domini ratings data. Business \& Society, 45(1), 20-46. https://doi.org/10.1177/0007650305281939

McGuire, J. B., Sundgren, A., \& Schneeweis, T. (1988). Corporate social responsibility and firm financial performance. Academy of Management Journal, 31(4), 854-872. https://doi.org/10.2307/256342

Ng, A., Yuce, A., \& Chen, E. (2009). Determinants of state equity ownership, and its effect on value/ performance: China’s privatized firms. Pacific-Basin Finance Journal, 17(4), 413-443. https://doi.org/10.1016/j.pacfin.2008.10.003

Peloza, J., \& Papania, L. (2008). The missing link between corporate social responsibility and financial performance: Stakeholder salience and identification. Corporate Reputation Review, 11(2), 169-181. https://doi.org/10.1057/crr.2008.13

Portney, P. R. (2008). The (not so) new corporate social responsibility: An empirical perspective. Review of Environmental Economics and Policy, 2(2), 261-275. https://doi.org/10.1093/reep/ren003

Reimsbach, D., Braam, G., \& Wang, Z. (2018). Political embeddedness and the diffusion of corporate social responsibility practices in China: A trade-off between financial and CSR performance? Journal of Cleaner Production, 198, 1185-1197. https://doi.org/10.1016/j.jclepro.2018.07.116

Reitzig, M., \& Wagner, S. (2010). The hidden costs of outsourcing: Evidence from patent data. Strategic Management Journal, 31(11), 1183-1201. https://doi.org/10.1002/smj.852

Rhou, Y., \& Singal, M. (2020). A review of the business case for CSR in the hospitality industry. International Journal of Hospitality Management, 84, 1023-1030. https://doi.org/10.1016/j.ijhm.2019.102330

Rhou, Y., Singal, M., \& Koh, Y. (2016). CSR and financial performance: The role of CSR awareness in the restaurant industry. International Journal of Hospitality Management, 57, 30-39. https://doi.org/10.1016/j.ijhm.2016.05.007

Roberts, R. W. (1992). Determinants of corporate social responsibility disclosure: An application of stakeholder theory. Accounting, Organizations and Society, 17(6), 595-612.

https://doi.org/10.1016/0361-3682(92)90015-K 
Schwartz, M. S., \& Carroll, A. B. (2003). Corporate Social Responsibility: A three-domain approach. Business Ethics Quarterly, 13(4), 503-530. https://doi.org/10.5840/beq200313435

Semenova, N., \& Hassel, L. G. (2008). Industry risk moderates the relation between environmental and financial performance. Sustainable Investment Research Platform Working Papers, 08-02.

Shenzhen GTA Education Technology (2000). Company Profile. http://en.gtafe.com/14-7-173.html

Sroufe, R., \& Gopalakrishna-Remani, V. (2018). Management, Social sustainability, reputation, and financial performance relationships: An empirical examination of US firms. Organization \& Environment, 32(3), 331-362. https://doi.org/10.1177/1086026618756611

Surroca, J., Tribó, J. A., \& Waddock, S. (2010). Corporate responsibility and financial performance: The role of intangible resources. Strategic Management Journal, 31(5), 463-490. https://doi.org/10.1002/smj.820

Tabachnick, B. G., Fidell, L. S., \& Ullman, J. B. (2007). Using multivariate statistics. Pearson.

Tippayawong, K., Tiwaratreewit, T., \& Sopadang, A. (2015). Positive influence of green supply chain operations on Thai electronic firms' financial performance. Procedia Engineering, 118, 683-690. https://doi.org/10.1016/j.proeng.2015.08.503

Torugsa, N. A., O’Donohue, W., \& Hecker, R. (2012). Capabilities, proactive CSR and financial performance in SMEs: Empirical evidence from an Australian manufacturing industry sector. Journal of Business Ethics, 109(4), 483-500. https://doi.org/10.1007/s10551-011-1141-1

Turban, D. B., \& Greening, D. W. (1997). Corporate social performance and organizational attractiveness to prospective employees. Academy of Management Journal, 40(3), 658-672. https://doi.org/10.2307/257057

Waddock, S. A., \& Graves, S. B. (1997). The corporate social performance-financial performance link. Strategic Management Journal, 18(4), 303-319. https://doi.org/10.1002/(SICI)1097-0266(199704)18:4<303::AID-SMJ869>3.0.CO;2-G

Wang, H., Choi, J., \& Li, J. (2008). Too little or too much? Untangling the relationship between corporate philanthropy and firm financial performance. Organization Science, 19(1), 143-159. https://doi.org/10.1287/orsc.1070.0271

Wang, H., \& Qian, C. (2011). Corporate philanthropy and corporate financial performance: The roles of stakeholder response and political access. Academy of Management Journal, 54(6), 1159-1181. https://doi.org/10.5465/amj.2009.0548

Wei, J., \& Li, R. (2003). Chinese corporate culture, Confucianism, Taoism and Buddhism. Chinese and Foreign Management, 3, 36-38.

Wen, S. B., \& Fang, Y. (2008). Empirical study on the relationship between corporate social responsibility and financial performance - analysis on panel data from stakeholder perspective. China Industrial Economics, 10, 150-159.

$\mathrm{Xu}, \mathrm{B} .$, \& Zeng, T. (2016). Profitability, state ownership, tax reporting and corporate social responsibility: Evidence from Chinese listed firms. Social Responsibility Journal, 12(1), 23-31. https://doi.org/10.1108/SRJ-06-2014-0076

Yang, X. (2011). Family businesses make up 85.4\% of private sector. Retrieved 02 March, 2020 from http://www.china.org.cn/learning_english/2011-12/13/content_24142565.htm

Yin, J. (2017). Institutional drivers for corporate social responsibility in an emerging economy: A mixed-method study of Chinese business executives. Business \& Society, 56(5), 672-704. https://doi.org/10.1177/0007650315592856

Yin, J., \& Zhang, Y. (2012). Institutional dynamics and corporate social responsibility (CSR) in an emerging country context: Evidence from China. Journal of Business Ethics, 111(2), 301-316. https://doi.org/10.1007/s10551-012-1243-4

Zhao, M. (2012). CSR-based political legitimacy strategy: Managing the state by doing good in China and Russia. Journal of Business Ethics, 111(4), 439-460. https://doi.org/10.1007/s10551-012-1209-6 